Boston University School of Law

Scholarly Commons at Boston University School of Law

Faculty Scholarship

1998

Partial-Birth Abortion, Congress, and the Constitution

George J. Annas

Follow this and additional works at: https://scholarship.law.bu.edu/faculty_scholarship

Part of the Health Law and Policy Commons 
Legal Issues in Medicine

\section{Partial-Birth Abortion, Congress, AND the Constitution}

George J. AnNAS, J.D., M.P.H.

$\mathrm{T}$

HE political debate over abortion during the past 25 years has shifted among various dichotomous views of the world: life versus choice, fetus versus woman, fetus versus baby, constitutional right versus states' rights, government versus physician, physician and patient versus state legislature. Hundreds of statutes and almost two dozen Supreme Court decisions on abortion later, the core aspects of Roe v. Wade, ${ }^{1}$ the most controversial healthrelated decision by the Court ever, remain substantially the same as they were in 1973. Attempts to overturn Roe in both the courtroom and the legislature have failed. Pregnant women still have a constitutional right to abortion. The fetus is still not a person under the Constitution. States still cannot make abortion a crime (either for the woman or the physician) before the fetus becomes viable. States still can outlaw abortion after the fetus becomes viable only if there is an exception that permits abortion to protect the life or health of the pregnant woman. And states still can impose restrictions on abortion before fetal viability only if those restrictions do not actually create a substantial obstacle to a pregnant woman's obtaining an abortion.

The current political tactic has shifted from the use of antiabortion rhetoric to change the law concerning abortion to the use of legislative and judicial forums to change the rhetoric of abortion. The hope seems to be that more heated rhetoric will help turn the public and physicians against abortion itself, regardless of its constitutionally protected status.

\section{ROE AND CASEY}

Twenty-five years ago, in Roe v. Wade, the Supreme Court held that women have a constitutional right of privacy that is "fundamental" and "broad enough to encompass a woman's decision ... to terminate her pregnancy." Because the right is fundamental, the state must demonstrate a "compelling state interest" in order to restrict it. The Court determined that the state's interest in the life of the fetus becomes compelling only at the point of "viability," defined as the point at which the fetus can survive independent of its mother. Moreover, the state cannot favor the life of the fetus over the life or health of the pregnant woman.
In Roe v. Wade, the Court held that even after a fetus becomes viable, physicians must be able to use their "medical judgment for the preservation of the life or health of the mother." Roe's companion case, Doe v. Bolton, specifically included mental health in this determination, saying, "The medical judgment may be exercised in the light of all factors - physical, emotional, psychological, familial, and the woman's age - relevant to the well-being of the patient. All these factors may relate to health. This allows the attending physician the room he needs to make his best medical judgment."

When the Court heard Planned Parenthood v. Casey $^{3}$ in 1992, most commentators assumed that there were more than enough votes to overturn Roe. Instead, three seemingly anti-Roe justices together wrote a joint opinion confirming the "core holding" of Roe: that states could not outlaw abortion before the fetus becomes viable and could do so thereafter only when the life or health of the woman was not threatened by continuing the pregnancy. ${ }^{3,4}$ With the loss of all hope that the Court would ever overturn Roe, antiabortion advocates needed a new approach to keep the abortion debate alive. They found it in so-called partial-birth abortions.

\section{PARTIAL-BIRTH ABORTION IN CONGRESS}

In June 1995, the first Partial-Birth Abortion Ban Act was introduced in Congress to make it a federal crime to perform "an abortion in which the person performing the abortion partially vaginally delivers a living fetus before killing the fetus and completing the delivery.” In March 1996, the House passed a revised Senate version, which provided in part:

(a) Whoever, in or affecting interstate or foreign commerce, knowingly performs a partial-birth abortion and thereby kills a human fetus shall be fined under this title or imprisoned not more than two years, or both.

(b) . . . the term partial-birth abortion means an abortion in which the person performing the abortion partially vaginally delivers a living fetus before killing the fetus and completing the delivery . . . . it is an affirmative defense . . . that the partial-birth abortion was performed by a physician who reasonably believed (1) the partial-birth abortion was necessary to save the life of the mother; and (2) no other procedure would suffice for that purpose. ${ }^{5}$

In April 1996, President Bill Clinton vetoed the bill at a White House press conference at which five women described how they had made the decision to terminate their pregnancies with what could be considered a partial-birth abortion under the proposed law. He said that the debate was "not about the prochoice/prolife debate" but about the tragic circumstances of "a few hundred Americans every year who desperately want their children." The President made it clear that he would sign a bill that was consistent with Roe v. Wade. In the President's words, "I will accept language that says serious, ad- 
verse health consequences to the mother. Those three words." 6

When the Senate voted in September 1996 to sustain the President's veto, the leader of the fight to override it was Senator Rick Santorum (R-Pa.), who was challenged as having no personal experience or expertise in this area. A week after the vote, Santorum had his own story to tell. ${ }^{7}$ The senator's wife had been pregnant with their fourth child when they were informed that ultrasonography showed that their child had a "fatal defect," which turned out to be complete urinary tract obstruction. They were given three options: have an abortion, do nothing, or choose in utero surgery to insert a shunt. They chose the shunt procedure, which was successfully performed at 20 weeks' gestation. The procedure resulted in infection that put Karen Santorum in serious danger. An abortion would have removed the source of her infection, but she refused. Instead, she went into labor and gave birth to an extremely premature infant, Gabriel. Two hours later he died in his parents' arms.

This seemed to give Santorum the personal experience to make him a more credible antiabortion advocate. But his experience also illustrates at least two major problems with the legislation he supports. First, his wife's actions can be considered praiseworthy only because she had a choice that is protected by current law. Second, the distinction between premature delivery and abortion on the edges of viability has always been problematic. Santorum, for example, has been quoted as having said, in relation to this experience, that even when the life of the mother is at stake and "you have to end a pregnancy early . . . that does not necessarily mean having an abortion. You can induce labor, using a drug like Pitocin [oxytocin]." ${ }^{\prime}$ If one accepts the standard medical definition of abortion (termination of a pregnancy when the fetus is not viable), this is a distinction without a difference. Whether a planned abortion is performed or labor is induced, both are intended to terminate a nonviable pregnancy. The real issue is not the method used to terminate the pregnancy, but the justification for terminating it. It is also reasonable to argue that after a fetus is viable, abortion is simply no longer possible by definition; the only option is premature delivery.

Moreover, what makes the term "partial-birth abortion" politically powerful is its inaccurate conflation of two polar-opposite results of pregnancy, birth and abortion. Senator Daniel Patrick Moynihan (D-N.Y.) has, for example, described it as "as close to infanticide as anything I have come upon." But close is not identical. When Virginia attorney general Mark Earley describes the procedure as a "disturbing form of infanticide," 10 he is making a legally inaccurate political statement. As the Supreme Court has repeatedly held, if the viable fetus is killed for the sake of the woman's life or health, the act is not infanticide by definition. ${ }^{1-4}$

\section{MEDICAL PRACTICE AND MEDICAL POLITICS}

In January 1997, Santorum reintroduced the Partial-Birth Abortion Ban Act in the Senate. Approximately one month later, the executive director of the National Coalition of Abortion Providers told reporters that he had lied in 1995 when he claimed that partial-birth abortions were rare and were performed only in extreme situations; instead, he said that "thousands" were performed annually, and most "on healthy fetuses and healthy mothers." "The total number of abortions performed in the United States has been steadily declining, although there seem to be no accurate statistics on the frequency of partial-birth abortions. There were two important differences in Congress this time around: medical organizations took conflicting positions, and substantial compromises were attempted in the Senate. The first time around, the American Medical Association (AMA) had taken no position, and the American College of Obstetricians and Gynecologists (ACOG) had urged the President to veto the bill.

In January 1997, ACOG's executive board issued its first and only statement on "intact dilatation and extraction." The board wrote that it understood that the bill attempted to outlaw a procedure containing all of the following four elements:

1. deliberate dilatation of the cervix, usually over a sequence of days;

2. instrumental conversion of the fetus to a footing breech;

3 . breech extraction of the body excepting the head; and

4. partial evacuation of the intracranial contents of the living fetus to effect vaginal delivery of a dead but otherwise intact fetus. ${ }^{12}$

The board described this as "one method of terminating a pregnancy" after 16 weeks. The board noted that it was sometimes used to save the life or health of the mother, but that its "select panel ... could identify no circumstances under which this procedure ... would be the only option to save the life or preserve the health of the woman ... [although it] may be the best or most appropriate procedure." The board's primary point was that only the woman's physician should make the decision about what particular procedure to use in individual circumstances, and that therefore "the intervention of legislative bodies into medical decision making is inappropriate, ill advised, and dangerous." 12

The AMA took a different position. On the eve of the Senate vote in May 1997, the AMA's board of trustees agreed to support the legislation if Santorum would add two physician-friendly procedural amendments. ${ }^{13}$ These were a requirement that the 
physician's action be "deliberate and intentional," and a procedure to involve the state medical board in the trial of an accused physician. State bans on partial-birth abortion are based on the inherent police power that states have to protect the health and safety of the public. The federal government has no such power; the federal bill is instead based on the power of Congress to regulate interstate commerce. Because the AMA endorsed the federal bill, it implicitly agreed that what physicians do with individual patients in their offices is a matter of interstate commerce, and therefore subject to regulation by the federal government. This is a stunning concession.

Attempts to reach a real compromise that could have resulted in a bill that President Clinton could sign, and that would probably have been upheld by the courts as constitutional, were made primarily by Senator Dianne Feinstein (D-Calif.), Senator Barbara Boxer (D-Calif.), and Senator Thomas Daschle (D-S.D.). The Feinstein-Boxer amendment would have dealt specifically with the problem the President had with the original bill by adding "serious adverse health consequences to the woman" as an additional exception to the prohibition. Daschle offered to ban all abortions, by any technique, after viability. The only exception would be to save the life of the pregnant woman or to protect her from "grievous injury" to her physical health, defined as "a severely debilitating disease or impairment specifically caused by the pregnancy, or an inability to provide necessary treatment for a life-threatening condition." 14

Daschle's bill defined the realm of the debate as the period after viability (roughly the third trimester) but nonetheless attempted to limit the reach of Roe v. Wade by restricting the exception regarding the health of the pregnant woman to physical (not mental) health and to the risk of "grievous" harm, at that. ACOG endorsed the Daschle compromise, but in doing so seemed to put politics over loyalty to patients, since the Daschle proposal limited the ability of a physician to act to protect the health of a patient after the fetus becomes viable.

In May 1997, the Senate adopted the Santorum bill by a vote of 64 to 36, and in October 1997, it was passed by the House and sent to the President. Two days later, President Clinton again vetoed the bill. He issued a three-paragraph message to the House of Representatives, in which he said he was vetoing the bill "for exactly the same reasons I returned an earlier substantially identical version . . . last year" - that is, because of its failure to include an exception for abortion to prevent "serious harm" to a woman's health. ${ }^{15}$

As Daschle's proposed compromise indicated, by 1997 the debate in Congress had begun to shift from a focus on partial-birth abortion to a more general focus on "late-term abortion." In this con- text, ACOG issued the following statement in July 1997: "ACOG is opposed to abortion of the healthy fetus that has attained viability in a healthy woman. Viability is the capacity of the fetus to survive outside the mother's uterus. Whether or not this capacity exists is a medical determination, may vary with each pregnancy and is a matter for the judgment of the responsible attending physician." 16

\section{GOVERNMENT REGULATION OF MEDICAL PROCEDURES}

Both sides admit that even if the technique of intact dilatation and extraction is outlawed, it is unlikely that even one abortion will be prevented. Thus, perhaps the primary lesson of the past 25 years is that the controversy over abortion in America is not susceptible to political solution. Moreover, since neither Congress nor the states can alter the constitutional law of abortion as set forth in Roe v. Wade ${ }^{1}$ and Casey, ${ }^{3}$ if the debate about partialbirth abortion were only a debate about abortion itself, it would be of little practical consequence. The debate, however, exposes other important issues.

The chief issue is the proper role of the government in regulating medical care. Historically, prochoice forces have favored this framing of the abortion debate. When the debate about abortion is argued as a choice between having a woman and her physician make the decision and having the state legislature or Congress make it, the woman and her physician are the overwhelming choice of Americans. The government-versus-physician framework is also uncomfortable for Republicans, who tend to argue against government interference with private decision making. And even when government regulation seems appropriate, most Republicans prefer regulation by the states to regulation by the federal government.

A more focused way to frame the debate is to ask whether decisions about specific medical procedures should be made by physicians or the Congress. The AMA's support of the ban on partial-birth abortion seems to be a repudiation of its historic position against government interference in this realm. If the AMA believes that the federal government can outlaw a constitutionally protected procedure performed in the privacy of a physician's office on the basis of the federal government's power to regulate interstate commerce, then the AMA has conceded that the federal government can regulate all medical procedures. On the other hand, the AMA has never had a consistent position on abortion. ${ }^{17}$

The issue of who (the medical profession or the state - or health plans, for that matter) has the authority to determine what is and what is not a legitimate medical procedure has implications for everything done by physicians, not just for abortions. ${ }^{18}$ Roe v. Wade and Casey both teach that government 
restrictions on legitimate medical procedures that are used to perform abortions before the fetus is viable are unconstitutional (at least if the use of such procedures does not increase the risks to the woman's health). These cases also teach that the failure to make exceptions to outlawed procedures (so that they can be used to protect the life and health of the pregnant woman) also makes the bills regulating partial-birth abortion unconstitutional as passed.

It has been primarily because of the failure to allow physicians to protect the woman's health after the fetus becomes viable, the vagueness of the definition of partial-birth abortion, and the application of the ban before fetal viability that courts have found that some of the similar laws regulating partial-birth abortion that have been passed in more than two dozen states are unconstitutional. ${ }^{19-24}$ Only in Wisconsin was the state statute not immediately enjoined, and because of its vagueness and the lifeimprisonment penalty provided for physicians who performed partial-birth abortions, abortion clinics in that state shut down for almost a week in the spring of 1998 until local district attorneys agreed not to use the statute to prosecute physicians who performed abortions before 16 weeks. ${ }^{25}$

In the only case to reach the Supreme Court so far, in March 1998, the Court refused to hear an appeal of a lower-court decision that the Ohio ban on partial-birth abortion was unconstitutional. Three justices (Clarence Thomas, Antonin Scalia, and William Rehnquist), however, voted to hear the appeal so that the Court could reopen what has become the central issue in the debate: whether the Constitution requires an exception to a ban on abortion after viability that includes the pregnant woman's mental health. ${ }^{26}$ Although we can only guess at why none of the other six justices voted to hear this case (it takes four justices to agree to hear an appeal to the Court), it would appear that all of them think that a woman's mental health is as protected under the Constitution as her physical health.

President Clinton is thus on strong constitutional grounds when he bases his vetoes on the failure of these bills to allow for a physician's action to preserve a pregnant woman's health. $\mathrm{He}$ is also on strong grounds in insisting, like ACOG, that the proper person to make a judgment about the health of the woman is the physician (acting, of course, in partnership with the woman). As the Court put it in Roe v. Wade, this "decision vindicates the right of the physician to administer medical treatment according to his professional judgment." "This means that if intact dilatation and extraction is a legitimate medical procedure, it is constitutionally protected under Roe v. Wade. If, however, it is not such a procedure, but rather is in the category of nonmedical interventions, like female genital mutilation ${ }^{27}$ and execution by lethal injection, it has (and deserves) no such protection. Therefore, another way to frame the debate about abortion is to ask who should have the authority to determine which procedures are legitimate medical procedures.

Efforts to reframe the abortion debate always involve a dichotomy that allows us to ignore or marginalize either women or fetuses by asking us to avert our attention from abortion itself and concentrate on something else. Often, this something else is the physician and the relation of medicine to government. At other times, it is (appropriately, I think) the pregnant woman and her life and health. Pregnancy is a unique human condition; there is nothing else like it in medicine or life, and we must therefore deal with it on its own terms, and not by analogy. To do so is simply impossible in the political arena. Because abortion foes have never seemed to care whether or not the laws they propose are unconstitutional, they have promised to make another attempt to override the Clinton veto if and when they can muster the three additional votes needed in the Senate to provide the two-thirds majority needed to override a presidential veto. ${ }^{28}$ Otherwise, the issue will return to the next Congress after the November election.

Professional organizations should set and follow the terms of their own specialties, and in this sense ACOG is the proper body to make this determination. But when professional organizations determine the content and scope of reasonable medical practice not on the basis of their professional skills and the health interests of their patients, but rather on the basis of their reading of the prevailing political winds, they undermine their own credibility and explicitly agree that standards for medical practice should be set by politicians rather than by the medical profession.

\section{REFERENCES}

1. Roe v. Wade, 410 U.S. 113 (1973)

2. Doe v. Bolton, 410 U.S. 179, 192 (1973)

3. Planned Parenthood of Southeastern Pennsylvania v. Casey, 502 U.S 1056 (1992).

4. Annas GJ. The Supreme Court, liberty, and abortion. N Engl J Med 1992;327:651-4.

5. H.R. 1833, 104th Cong.

6. Remarks on returning without approval to the House of Representatives partial birth abortion legislation. Weekly Compilation of Presidential Documents. April 10, 1996:643-7.

7. Santorum R. A brief life that changed our lives forever. National Right to Life News. May 23, 1997:6-7.

8. Klein J. The senator's dilemma. New Yorker. January 5, 1998:30-5

9. Vobejda B, Brown D. Harsh details shift tenor of abortion fight: both sides bend facts on late-term procedure. Washington Post. September 17, 1996:Al.

10. Hsu S. Virginia ban on certain abortions is blocked, law too vague U.S. judge says. Washington Post. June 26, 1998:C1.

11. Gianelli DM. Abortion rights leader urges end to 'half truths.' American Medical News. March 3, 1997:3, 28.

12. American College of Obstetrics and Gynecology. Statement on intact dilatation and extraction, January 12, 1997.

13. Gianelli DM. House affirms AMA stance on abortion. American Medical News. July 7, 1997:3, 30.

14. Seelye KQ. Democratic leader proposes measure to limit abortions. New York Times. May 9, 1997:A32. 
15. Message to the House of Representatives returning without approval partial birth abortion legislation. Weekly Compilation of Presidential Documents. October 10, 1997:1545.

16. American College of Obstetrics and Gynecology. Addendum to the reaffirmed 1993 ACOG policy on abortion. July 1997.

17. Wolinsky $\mathrm{H}$, Brune $\mathrm{T}$. The serpent on the staff: the unhealthy politics of the American Medical Association. New York: G.P. Putnam's Sons, 1994.

18. Kassirer JP. Practicing medicine without a license - the new intrusions by Congress. N Engl J Med 1997;336:1747.

19. Women's Medical Professional Corp. v. Voinovich, 130 F. 3d 187 (6th Cir. 1997).

20. Planned Parenthood of So. Arizona v. Woods, 982 F. Supp. 1369 (D Arizona 1997)

21. Carhart v. Stenberg, 972 F. Supp. 507 (D. Nebraska 1997).
22. Summit Medical Associates v. James, 984 F. Supp. 1404 (M.D. Alabama 1998 )

23. Evans v. Kelley, 977 F. Supp, 1283 (E.D. Michigan 1997)

24. Massie AM. So-called "partial-birth abortion" bans: bad medicine? Maybe. Bad law? Definitely! U P H L Rev 1998;59:301-80.

25. Jeter J. Reassured by prosecutors on new law, Wisconsin clinics resume abortions. Washington Post. May 20, 1998:A8.

26. Voinovich v. Women's Medical Professional Corp., 118 S. Ct. 1347 (1998)

27. Annas CL. Irreversible error: the power and prejudice of female genital mutilation. J Contemp Health Law Policy 1996;12:325-53.

28. Lewin $T$. Wisconsin abortion clinics shut down, citing new law. New York Times. May 15, 1998:Al6.

C1998, Massachusetts Medical Society. 